\title{
Incidences and Bio-Detoxification of Aflatoxins in Rice and Cattle Feed Crops under Different Agro-Ecological Zones
}

\author{
Arif Nazir ${ }^{1 * *}$, Imran Kalim², Must Imran' ${ }^{1}$, Muhammad Ahsen Bilal ${ }^{1}$, Naseem Zahra ${ }^{3}$, \\ Aftab Ahmad ${ }^{4 *}$, Munawar Iqbal ${ }^{1}$, Uroosa Fazal ${ }^{5}$, Syed Ehtisham-ul-Haque ${ }^{6}$ \\ ${ }^{1}$ Department of Chemistry, The University of Lahore, Lahore, Pakistan \\ ${ }^{2}$ Food and Biotechnology Research Centre, PCSIR Laboratories Complex, Lahore, Pakistan \\ ${ }^{3}$ College of Earth and Environmental Sciences, University of the Punjab, Lahore, Pakistan \\ ${ }^{4}$ Department of Biochemistry/Centre for Advanced Studies in Agriculture and Food Security (USPCASAFS), \\ University of Agriculture, Faisalabad, Pakistan \\ ${ }^{5}$ Department of Biochemistry, University of Gujrat, Hafiz Hayat Campus, Gujrat, Pakistan \\ ${ }^{6}$ CVAS, Jhang Campus, University of Veterinary and Animal Sciences, Lahore, Pakistan
}

Received: 18 January 2020

Accepted: 26 April 2020

\begin{abstract}
This research was carried out to monitor the occurrence of aflatoxins (B1, B2, G1, and G2) in unpacked rice (50 samples) and cattle feed (60 samples). These samples were analyzed using TLC \& ELISA techniques. $30 \%$ rice samples showed aflatoxins (AFTs) in the range of 1-20 ppb while $10 \%$ samples showed AFTs above $20 \mathrm{ppb}$. For cattle feed, AFTs detected in the range of 1.9-20.4 ppb in maize, 9.6-28.5 ppb in corn, 9.8-27.3 ppb in barely, 5.4-21.3 ppb in hay samples and 6.7-28.5 ppb in silage samples. The contaminated samples were treated for detoxification. The detoxification promised by specific natural compounds like sodium bicarbonate, citric acid, Allium sativum and black seed oil were from $63-100 \%$. The foods contaminated with AFTs are toxic for human health. High doses of AFTs can be the major cause of liver diseases like cirrhosis, liver cancer and death in humans and animals.
\end{abstract}

Keywords: aflatoxins, cattle feed, detoxification, ELISA, Pakistan, rice crops

\section{Introduction}

Rice is a widely used dominant grain after wheat and is a staple food crop of various world populations [1]. Rice is a vital cereal crop, which is consumed as

*e-mail: aftab.ahmad@uaf.edu.pk

**e-mail: malikanphd2013@yahoo.com essential staple foodstuff in Pakistan. Basmati rice varieties are well known in whole world for quality, aroma and delicious taste. Pakistan is a central rice exporter because it is foremost cash food contributing $1.3 \%$ to the gross domestic product (GDP) [2-5]. Aflatoxin quantity would be linked with highest tolerable aflatoxin value (4 ppb). Rice shows resistance against the desert, humid, flood, hot, dry and cool 
conditions and has ability to grow in the alkaline, acidic and saline soil $[6,7]$. In Pakistan, the average production is about 4.9 tons/ha, that makes the country 11th biggest rice producer in the world [8]. Various rice varieties in Pakistan are super kernel, basmati, kainaat and super Shaheen etc.

AFTs are common mycotoxin which affects the crops especially staple food (wheat, rice, maize and grains). High temperature and humidity are favorable conditions for fungus growth [9]. International Agency for Research on Cancer (IARC) ranked some materials as class one carcinogen in which AFTs also involved. Aspergillus flavus, Aspergillus parasiticus, Aspergillus nomius and Aspergillus pseudotamarii are the fungi that are responsible for the production of AFTs [10-12]. Different food commodities that have great chances of contaminations from AFTs include maize, corn, barely, silage, milk and hay etc. Mycotoxins cause the serious complications for animal and human health. These are contaminants of vital plant products like oil seeds, nuts, spices, corn, rice, barley and wheat [13]. Mycotoxins maximum levels are fixed by specific countries for different types of food products. AFTs are significant mycotoxins for foodstuff contaminants worldwide, especially for the developing countries. The important types of the AFTs are AFG1, AFG2, AFB1, AFB2, AFM1 and AFM2. AFB1 is the vital toxic variety as compared to other AFTs and it is the most persuasive human carcinogen. AFB1 type is categorized into the groups of carcinogenic compounds through the IARC of World Health Organization (WHO) [8]. AFB1 remain stable during processing operations. These contaminations may lead to huge economic damages in various countries. Different countries have specific regulations to control the mycotoxin levels in plant and dairy products [13]. European Unions have established the maximum tolerable limits for the AFTs in rice products as $4 \mathrm{ppb}$ for the total AFTs $(\mathrm{G} 1+\mathrm{G} 2+\mathrm{B} 1+$ B2) and $2 \mathrm{ppb}$ for AFB1 (Commission Regulation No. 1881/2006). Pakistan standard quality control authority has made a limit of $5 \mathrm{ppb}$ for the AFB1 in rice products. Various methods can be used for the analysis of AFTs including the high performance liquid chromatography (HPLC), thin layer chromatography (TLC) and ELISA [14]. ELISA is the simplest method which has advantages as being selective, rapid, monotonous reliable and diagnostic analysis of various samples [13].

The purpose of this research was to find out the existence of AFTs in Pakistani rice and cattle feed and to determine the conditions responsible and ultimately to control AFTs production. It would be helpful to reduce the chances of hepatocellular carcinoma, immune super sensitivity and encephalopathy etc.

\section{Material and Methods}

Rice \& cattle feed samples were collected different regions of Punjab, Pakistan (Table 1). All types of samples were changed into powdered form using Molineux blender. $500 \mathrm{~g}$ of each sample was stored at $4-6^{\circ} \mathrm{C}$ in the sealed plastic bags for analysis [15].

\section{Thin Layer Chromatography Technique (TLC)}

The dilutions were made for spotting using micro syringe. Spot of $25 \mu \mathrm{L}$ of test solution was applied on TLC plate. Standard spots of 5 and $10 \mu \mathrm{L}$ of the AFTs (AFG1, AFG2, AFB1, and AFB2) were also spotted on the plate as an internal standard. The plate of TLC was placed in TLC Tank 1 ( $\left(1^{\text {st }}\right.$ mobile phase $)$ containing the anhydrous ether until the solvent moved half way up. After this, TLC plate was developed and it was dried. The redevelopment of the plate was done in similar direction but along with solution of chloroform and acetone to a ratio of 9:1 in the TLC Tank 2 . After the exclusion of TLC plate from TLC Tank 2 ( $2^{\text {nd }}$ mobile phase), spots were dehydrated and observed under the UV Light for the absence or presence of AFTs [16].

\section{ELISA Analysis of AFB1}

The quantitative examination of AFB1 in the samples was done, based on the competitive enzyme immunoassay via Ridascreen ${ }^{\circledR}$ Aflatoxin $B_{1} \quad 30 / 15$ test kit (R-Biopharma, Darmstadt, Germany). $25 \mathrm{~mL}$ methanol: water (70:30) was added to the $5 \mathrm{~g}$ sample and shaken robustly for $3 \mathrm{~min}$. The extract was filtered and diluted with distilled water (1:1). At the end, $50 \mathrm{~mL}$ of the diluted remainders per well were used in the test. $50 \mathrm{~mL}$ of each prepared sample or standard solution in duplicate, antibody solution and enzyme conjugate were added to each micro titer well, mixed and incubated for $30 \mathrm{~min}$ at $25^{\circ} \mathrm{C}$. The liquid was eliminated from the well through tapping of wells and were washed twice using buffer. The $100 \mathrm{~mL}$ of the substrate or chromogen solution was added to each micro titer well, mixed and incubated for $15 \mathrm{~min}$ at $25^{\circ} \mathrm{C}$ in dark. Finally, the $100 \mathrm{~mL}$ of stock solution $\left(1 \mathrm{~N} \mathrm{H}_{2} \mathrm{SO}_{4}\right)$ was added to each micro titer well. The absorbance was measured at $450 \mathrm{~nm}$.

\section{Detoxification}

Process of detoxification for the reducing type AFB1was done on the $50 \mathrm{~g}$ of sample products that are naturally contaminated. For more accurate study, $100 \mathrm{~g}$ of uncontaminated samples were spiked for contamination. After that, both types of the samples were mixed with each other to increase the homogeneity of AFTs and were examined by TLC. Samples were detoxified through Allium sativum treatment [17], Nigella sativa [18] oil treatment, citric acid treatment [19] and sodium bicarbonate treatment [20]. These treatments were performed at $26^{\circ} \mathrm{C}$ for $30 \mathrm{~min}$ in the fuming hood. 
Table 1. Quantity of AF B1 present in representative rice \& cattle feed samples.

\begin{tabular}{|c|c|c|c|}
\hline Sr. \# & Sampling location & Rice Types & AFs Conc. (ppb) \\
\hline 1 & Mandibahaudin & Basmati 198 & 3.5 \\
\hline 2 & Bhimber AJK & Pak Basmati & 4.5 \\
\hline 3 & Kotla arab ali khan & Broken white basmati & 7.2 \\
\hline 4 & Jalal pur jattan & Super kernel brown & 3.6 \\
\hline 5 & Gujranwala bypass & Basmati sella rice & 5.7 \\
\hline 6 & Gujranwala saddar & 1121 Basmati rice & 2.6 \\
\hline 7 & Mandibahaudin phatak & Brown basmati rice & 20.1 \\
\hline 8 & Gujrat ZI stadium & Kernel rice & 14.6 \\
\hline 9 & Kharian road guliana & Super kernel & 6.5 \\
\hline 10 & Sialkot cantonment & KS 282 brown & 2.4 \\
\hline 11 & Lahore TNB & Super basmati & 3.6 \\
\hline 12 & Lahore anarkali & Basmati rice & 9.5 \\
\hline \multicolumn{4}{|c|}{ Cattle Feed } \\
\hline 1 & Paropi Sialkot & \multirow{2}{*}{ Maize } & 1.9 \\
\hline 2 & Miana Pura Sialkot & & 20.4 \\
\hline 3 & Head Marala Sialkot & \multirow{2}{*}{ Corn } & 9.6 \\
\hline 4 & Lakhan Pur Sialkot & & 28.5 \\
\hline 5 & Gujranwala Lohianwala & \multirow{2}{*}{ Barely } & 27.3 \\
\hline 6 & Gujranwala Gondlawala & & 9.8 \\
\hline 7 & Muslim Town Lahore & \multirow{2}{*}{ Hey } & 21.3 \\
\hline 8 & Tulspura Lahore & & 1.9 \\
\hline 9 & Fatehgarh Sialkot & \multirow{2}{*}{ Silages } & 6.7 \\
\hline 10 & Lakhan Pur Sialkot & & 28.5 \\
\hline
\end{tabular}

\section{Results and Discussion}

AFB1 was identified in the 12 positive rice samples. The occurrence and AFB1 levels in rice samples are showed in Table 1. The limit values of AFB1 contaminations were from 1.5 to $20.1 \mathrm{ppb}$, and 7 rice samples surpassed the ISIRI limit of $4 \mathrm{ppb}$ for AFB1. Aflatoxin G1, G2, B2 was not present and detected. Various limits of the aflatoxin tolerance are set through the EU i.e. 2 ppb for rice and in other types of processed products. FDA allows the range $2-4$ ppb in feed products and $2 \mathrm{ppb}$ for all the food used for human consumption. The highest aflatoxin amount was detected in the one sample of rice (20.1 ppb), that was beyond the WHO and FDA regulations. The recommended limit by WHO is $3 \mathrm{ppb}$ for rice.

Food samples of various food commodities were analyzed for the analysis of aflatoxins in cattle feedstuff. Out of 60 feed samples of maize, corn and barley, hay and silage the aflatoxin was detected in 25 samples. These contaminated samples were treated with natural ingredients to detoxify the aflatoxins. The presence of AFB1 was usually detected in almost all types of feed items. Other aflatoxins including B2, G1 and G2 were not common. The feed items were contaminated and shown positive results for aflatoxin detection (AFB1 1.9 ppb-28.7 ppb). 5 out of 12 sample of maize were contaminated with aflatoxin ranging from (1.9 ppb-20.4 ppb). The Aflatoxin contamination level for maize set by EU (European Union) is $\geq 20$ ppb. 3 out of 5 contaminated samples were below the permissible limit set by EU. 7 out of 12 samples of corn were contaminated with aflatoxin ranging from $9.6 \mathrm{ppb}-28.5 \mathrm{ppb}$. 4 out of 7 contaminated samples were below the permissible limit set by EU while the 3 out of 7 contaminated samples were above the limits with aflatoxin contamination i.e. $20.9 \mathrm{ppb}$, $23.2 \mathrm{ppb}$ and $28.5 \mathrm{ppb}$. Similarly, 4 samples of barley were contaminated with aflatoxin ranging from 9.8 ppb-27.3 ppb. 3 out of 12 samples of hay and 6 out of 12 samples of silage were contaminated with aflatoxin ranging from $1.9 \mathrm{ppb}-21.3 \mathrm{ppb}$ and 
Table 2. Aflatoxins detoxification using natural compounds.

\begin{tabular}{|c|c|c|c|c|}
\hline Sample & AFs (ppb) before treatment & Treatment & AFs (ppb) after treatment & Reduction (\%) \\
\hline \multirow{4}{*}{ Rice } & \multirow{4}{*}{20.1} & Allium sativum & 2.4 & 88 \\
\hline & & Black Seed Oil & 0 & 100 \\
\hline & & Citric Acid & 7.43 & 63 \\
\hline & & Sodium Bicarbonate & 4.0 & 80 \\
\hline \multirow{4}{*}{ Maize } & \multirow{4}{*}{20.4} & Allium sativum & 0.41 & 98 \\
\hline & & Black Seed Oil & 0 & 100 \\
\hline & & Citric Acid & 2.73 & 90 \\
\hline & & Sodium Bicarbonate & 4.26 & 80 \\
\hline \multirow{4}{*}{ Corn } & \multirow{4}{*}{28.5} & Allium sativum & 1.42 & 95 \\
\hline & & Black Seed Oil & 0 & 100 \\
\hline & & Citric Acid & 5.7 & 80 \\
\hline & & Sodium Bicarbonate & 6.27 & 78 \\
\hline \multirow{4}{*}{ Barely } & \multirow{4}{*}{27.3} & Allium sativum & 1.91 & 93 \\
\hline & & Black Seed Oil & 0 & 100 \\
\hline & & Citric Acid & 4.09 & 85 \\
\hline & & Sodium Bicarbonate & 5.73 & 79 \\
\hline \multirow{4}{*}{ Hey } & \multirow{4}{*}{21.3} & Allium sativum & 0.64 & 97 \\
\hline & & Black Seed Oil & 0 & 100 \\
\hline & & Citric Acid & 2.77 & 87 \\
\hline & & Sodium Bicarbonate & 3.83 & 82 \\
\hline \multirow{4}{*}{ Silages } & \multirow{4}{*}{28.5} & Allium sativum & 1.14 & 96 \\
\hline & & Black Seed Oil & 0 & 100 \\
\hline & & Citric Acid & 3.13 & 89 \\
\hline & & Sodium Bicarbonate & 5.7 & 80 \\
\hline
\end{tabular}

6.7 ppb-28.5 ppb respectively. 1 sample of hay \& 3 samples of silage were above the EU.

Presence of the toxic fungus in products of food is not beneficial for health. Therefore, its removal and reduction become necessary for human health. Aflatoxin detoxification was carried out through the natural ingredients like garlic, citric acid, black seed oil and sodium bicarbonate were used for fungus reduction $[4,5,21,22]$. Numerous studies describe the AFB1 contamination in the various varieties of the rice. In the earlier study [23] from China they examined that the incidence and concentration limit of the AFTs in 30 samples of rice were examined through the HPLC FLD. They stated that AFB1 and AFB2 were found in the $46.7 \%$ samples with a limit value of (0.03-2.08 ppb). Only one rice sample was found above EU regulatory range for AFB1. Our research results revealed that 35\% samples of rice were contaminated with AFB1.

\section{Detoxification of Aflatoxins Using Natural Compounds}

\section{Allium sativum Treatment}

This study shows that Allium sativum extracts have antifungal activity against A. flavus and during detoxification, $88 \%$ to $98 \%$ AFTs reduction was recorded (Table 2). The repressive functionality of specific extracts of Allium sativum vegetables against mould specie has been identified and reported by the various authors. Previous studies reported the extracts of nine plants that were analyzed. A. sativum specifically inhibited the A. flavus growth (65-78\%) and production of aflatoxin AFB1 from 12.2 to $15.7 \%$ at the 5-ppb concentration. Diallyl sulfide and Ajoene, organosulfur compounds in the garlic hinders the binding of DNA to aflatoxin. Garlic has different types 
of antioxidant characteristics and its uses have been reported to help irregularities of cardiac, thrombus formation and hyperlipidemia.

\section{Black Seed Oil Treatment}

$N$. sativa, black seeds, are made up with different types of bioactive chemicals and many other antioxidants which have great inhibitory characteristics [24]. The contaminated samples were treated with the black seed oil to prevent the AFB1 contamination. Oil of black seed was extremely efficient and reduced the contamination up to $100 \%$. Oils of Nigella sativa was known, for its antifungal functionality against the all types of tested fungi. An oil of Nigella sativa was most effective at $0.15 \%$ e.g. $F$. moniliforme and A. alternata were completely inhibited at the $0.1 \%$ and $0.15 \%$ concentrations [10, 24, 25].

\section{Lemon Juice Treatment}

Citric acid $\left(\mathrm{C}_{6} \mathrm{H}_{8} \mathrm{O}_{7}\right)$ was used for the preservation processes. It has specific, unique, acidic and tangy flavors, added into various types of drinks and foods. Juice of lemon consist of the $5 \%$ citric acid. Treatment through the aqueous citric acid detoxified AFB1 in the rice. In this research contaminated samples were soaked in lemon juice for detoxification. The results of that process showed that citric acid was $63.59 \%$ to $90 \%$ effective, against the aflatoxin B1 in the different varieties tested. A recent research determined that citric acid and lemon pistachio nuts, were roasted which was degraded over the $70 \%$ AFB1 $[26,27]$.

\section{Sodium Bicarbonate Treatment}

In this research, the samples contaminated with AFTs were soaked in the $\mathrm{NaHCO}_{3}$ and washed with distilled water thrice for decontamination of AFTs. This results up to $80.02 \%$ degradation of AFB1 in rice and cattle feed. In another research [11], mycotoxins types of aflatoxin were reduced by the $44 \%$ in samples of corn in addition with a single rinsing step. Moreover, contaminated samples that are soaked in $0.1 \mathrm{~mol} / \mathrm{L}$ aqueous solution of $\mathrm{NaHCO}_{3}$ for longer periods are degraded zearalenone (ZEN) and deoxynivalenol (DON) concentrations by $35 \%$.

\section{Conclusions}

Commodities contaminated with AFTs consumed regularly may cause severe harm. This study evaluated AFB1 in rice \& cattle feed from Punjab, Pakistan. In this study, 12 out of the 50 rice samples showed AFTs (1.5 to $20 \mathrm{ppb}$ ). Maize, grains, corn, silage and hay are prone to AFTs contamination. 25 out of 60 cattle feed samples showed AFTs presence (1.9-28.5 ppb). The food and feed must be analyzed on daily basis to protect the public from AFTs contamination. However, to minimize the AFTs production and reduction in fungal growth, specific measures must be taken during the processes like transport, storage, drying, harvesting and collection process.

\section{References}

1. ELZUPIR A.O., ALAMER A.S., DUTTON M.F. The occurrence of aflatoxin in rice worldwide: a review. Toxin Rev. 34 (1), 37, 2015.

2. KHAN A.S., ARIF K., MUNIR B., KIRAN S., JALAL F., QURESHI N., HASSAN S.M., SOOMRO G.A., NAZIR A., GHAFFAR A., TAHIR M.A., IQBAL M. Estimating Total Phenolics in Taraxacum officinale (L.) Extracts. Pol. J. Environ. Stud. 28 (1), 497, 2019.

3. ARSHAD M., HUSSAIN T., CHAUDHRY N., SADIA H., ASLAM B., TAHIR U., ABBAS M., QURESHI N., NAZIR A., RAJOKA M.I., IQBAL M. Enhancing Profitability of Ethanol Fermentation through Gamma Ray Mutagenesis of Saccharomyces cerevisiae. Pol. J. Environ. Stud. 28 (1), 35, 2019.

4. SULEMAN M., NOUREN S., HASSAN S.M., FAIZ A.H., SAHR G.A., SOOMRO G.A., TAHIR M.A., IQBAL M., NAZIR A. Vitality and Implication of Natural Products from Viburnum Grandiflorum: an Eco-Friendly Approach. Pol. J. Environ. Stud. 27 (3), 1407, 2018

5. MUNIR A., SULTANA B., BASHIR A., GHAFFAR A., MUNIR B., SHAR G.A., NAZIR A., IQBAL M. Evaluation of Antioxidant Potential of Vegetables Waste. Pol. J. Environ. Stud. 27 (2), 947, 2018.

6. MOUHAMAD R., JAAFAR Z., EL-KAABY E., IQBAL M., NAZIR A. Evaluation of Agronomic Traits and Inorganic Nutritional Composition of Rice Seed from IRSSTN Genotypes in Iraq. J. Rice. Res. 6 (189), 2, 2018.

7. MOUHAMAD R.S., MUTLAG L.A., ATIYAH A.H., RAZAQ I.B., ABDULHUSSEIN M.A., IQBAL M., NAZIR A. Salinity tolerance at seedling stage for rice genotypes: In vitro analysis. Net J. Agric. Sci. 5 (4), 126, 2017.

8. ESLAMI M., MASHAK Z., HESHMATI A., SHOKRZADEH M., MOZAFFARI NEJAD A.S. Determination of aflatoxin B1 levels in Iranian rice by ELISA method. Toxin Rev. 34 (3), 125, 2015.

9. SABAHAT A., BHATTI I.A., ASI M.R., BHATTI H.N., SHEIKH M.A. Occurrence of aflatoxins in maize grains from central areas of Punjab, Pakistan. Int. J. Agric. Biol. 12 (4), 571, 2010.

10. NAZIR A., KALIM I., SAJJAD M., USMAN M., IQBAL M. Prevalence of aflatoxin contamination in pulses and spices in different regions of Punjab. Chem. Int. 5 (4), 274, 2019.

11. IQBAL M., ABBAS M., ADIL M., NAZIR A., AHMAD I. Aflatoxins biosynthesis, toxicity and intervention strategies: A review. Chem. Int. 5 (3), 168, 2019.

12. HASSAN S.M., IQBAL M., BOKHARI T.H., NISAR N., TAHIR M.A., ABBAS M., KANWAL Q., IQBAL D.N., NAZIR A. Fungal infestation and aflatoxins synthesis control in stored poultry feed using medicinal plants. Environ. Technol. Innovat. 7, 194, 2017.

13. MOZAFFARI NEJAD A.S., SABOURI GHANNAD M., KAMKAR A. Determination of aflatoxin B1 levels in Iranian and Indian spices by ELISA method. Toxin Rev. 33 (4), 151, 2014. 
14. MATABARO E., ISHIMWE N., UWIMBABAZI E., LEE B.H. Current immunoassay methods for the rapid detection of aflatoxin in milk and dairy products. Comprehensive Rev. Food Sci. Food Saf. 16 (5), 808, 2017.

15. SANI A.M., AZIZI E.G., SALEHI E.A., RAHIMI $\mathrm{K}$. Reduction of aflatoxin in rice by different cooking methods. Toxicol. Ind. Heal. 30 (6), 546, 2014.

16. SHOTWELL O.L., HESSELTINE C., STUBBLEFIELD R., SORENSON W. Production of aflatoxin on rice. Appl. Microbiol. 14 (3), 425, 1966.

17. VIJAYANANDRAJ S., BRINDA R., KANNAN K., ADHITHYA R., VINOTHINI S., SENTHIL K., CHINTA R.R., PARANIDHARAN V., VELAZHAHAN R. Detoxification of aflatoxin B1 by an aqueous extract from leaves of Adhatoda vasica Nees. Microbiol. Res. 169 (4), 294, 2014.

18. EL-NEKEETY A.A., EL-KADY A.A., ABDELWAHHAB K.G., HASSAN N.S., ABDEL-WAHHAB M.A. Reduction of individual or combined toxicity of fumonisin B1 and zearalenone via dietary inclusion of organo-modified nano-montmorillonite in rats. Environ. Sci. Pollut. Res. 24 (25), 20770, 2017.

19. RASTEGAR H., SHOEIBI S., YAZDANPANAH H., AMIRAHMADI M., KHANEGHAH A.M., Campagnollo F.B., Sant'Ana AS. Removal of aflatoxin B1 by roasting with lemon juice and/or citric acid in contaminated pistachio nuts. Food Cont. 71, 279, 2017.

20. SAMARAJEEWA U., SEN A., COHEN M., WEI C. Detoxification of aflatoxins in foods and feeds by physical and chemical methods. J. Food Protec. 53 (6), 489, 1990.
21. QAMAR A., ASI R., IQBAL M., NAZIR A., ARIF K. Survey of Residual Pesticides in Various Fresh Fruit Crops: A Case Study. Pol. J. Environ. Stud. 26 (6), 2703, 2017.

22. SYTYKIEWICZ H., CHRZANOWSKI G., CZERNIEWICZ P., LESZCZYŃSKI B., SPRAWKA I., KRZYŻANOWSKI R., MATOK H. Antifungal Activity of Juglans regia (L.) Leaf Extracts Against Candida albicans Isolates. Pol. J. Environ. Stud. 24 (3), 1339, 2015.

23. LAI X., LIU R., RUAN C., ZHANG H., LIU C. Occurrence of aflatoxins and ochratoxin A in rice samples from six provinces in China. Food Cont. 50, 401, 2015.

24. KHOSRAVI A., MINOOEIANHAGHIGHI M., SHOKRI H., EMAMI S., ALAVI S., ASILI J. The potential inhibitory effect of Cuminum cyminum, Ziziphora clinopodioides and Nigella sativa essential oils on the growth of Aspergillus fumigatus and Aspergillus flavus. Braz. J. Microbiol. 42 (1), 216, 2011.

25. SALADINO F., LUZ C., MANYES L., FERNÁNDEZFRANZÓN M., MECA G. In vitro antifungal activity of lactic acid bacteria against mycotoxigenic fungi and their application in loaf bread shelf life improvement. Food Cont. 67, 273, 2016.

26. KARLOVSKY P., SUMAN M., BERTHILLER F., DE MEESTER J., EISENBRAND G., PERRIN I., OSWALD I.P., SPEIJERS G., CHIODINI A., RECKER T. Impact of food processing and detoxification treatments on mycotoxin contamination. Mycotox. Res. 32 (4), 179, 2016.

27. SAFARA M., ZAINI F., HASHEMI S.J., MAHMOUDI M., KHOSRAVI A.R., SHOJAI-ALIABADI F. Aflatoxin detoxification in rice using citric acid. Iran. J. Pub. Heal. 39(2), 24, 2010. 